\title{
RACIAL INFLUENCE ON THE PREVALENCE OF PROSTATE CARCINOMA IN BRAZILIAN VOLUNTEERS
}

\author{
EDSON L. PASCHOALIN, ANTONIO C.P. MARTINS, MÔNICA PASTORELLO, KIYOKO A. \\ SÂNDIS, LEA M.Z. MACIEL, WILSON A. SILVA JR., MARCOS A. ZAGO, JOSÉ BESSA JR. \\ Ribeirão Preto General Hospital, School of Medicine, USP, São Paulo, Brazil
}

\begin{abstract}
Purpose: To investigate the prevalence of prostate carcinoma in a sample of volunteers known to have a large proportion of Bantu African ancestors, and the performance of total PSA (tPSA), PSA density (PSAD) and free-to-total PSA ratio (f/tPSA) on the diagnosis.

Materials and Methods: A total of 473 volunteers (range: 40 - 79 years) were screened for prostate carcinoma. Those with tPSA $>2 \mathrm{ng} / \mathrm{ml}$ and/or abnormal digital rectal examination were submitted to a transrectal ultrasound-directed biopsy (10 cores). The volunteers were classified as White, Mulatto or Black according to physical characteristics and to ancestors race reference. The following variable number of tandem repeats (VNTR) were analyzed in the blood of 120 volunteers without cancer and in 27 patients with prostate cancer: D4S43, PAH, F13A1, APOB and vW-1.

Results: The biopsies performed in 121 volunteers revealed cancer in 27 (5.7\% of 473). The proportions of cancer in White, Mulatto and Black were respectively: $0.6 \%(1 / 148), 6.7 \%(6 / 90)$ and $8.5 \%(20 / 235)(p=0.006)$. The VNTRs analysis revealed heterogeneity in White, Mulatto and Black anthropologic phenotypes with the following admixture of Caucasian, African and Amerindian gene lineages: $67.5 \pm 8 \%, 20.8 \pm 8 \%, 11.7 \pm 7 \% ; 54.8 \pm 9 \%, 36.3 \pm 5 \%, 8.9 \pm 7 \%$; and $45.3 \pm 3 \%, 45.9 \pm$ $4 \%, 8.8 \pm 7 \%$. Such a mixture was $50.5 \pm 9 \%, 49 \pm 8 \%$ and $0.5 \pm 4 \%$ in volunteers bearing cancer, and $59.1 \pm 7 \%, 31.7 \pm 8 \%$ and $9.2 \pm 5 \%$ in those without cancer. The sensitivity and specificity of tPSA at cut-off levels of $2,2.5$ and $4 \mathrm{ng} / \mathrm{ml}$ for volunteers with $\mathrm{tPSA} \leq 10 \mathrm{ng} / \mathrm{ml}$ were respectively: $100 \%$ and $6,6 \%, 100 \%$ and $36,6 \%, 69,2 \%$ and $62,2 \%$. PSAD at a cut-off level of 0.08 or 0.10 , and f/tPSA at a cut-off level of $20 \%$ were able to increase significantly tPSA specificity without loss on sensitivity.

Conclusions: The tumor prevalence was higher in Non-White than in White phenotype. The association of tPSA at a cut-off level of $2.5 \mathrm{ng} / \mathrm{ml}$ with a PSAD of 0.08 or a f/tPSA of $20 \%$ for biopsy indication deserves further investigations as an alternative to tPSA cut-off level of $4 \mathrm{ng} / \mathrm{ml}$.
\end{abstract}

Key words: prostatic neoplasms; prevalence; race; prostate-specific antigen

Int Braz J Urol. 2003; 29: 300-5

\section{INTRODUCTION}

The prevalence of prostate adenocarcinoma is $50 \%$ higher in North-American Afro-American than in Caucasians, and it can be 3 or 4 times higher when compared to Chinese and Japanese (1). At the moment of diagnosis in Afro-Americans, the stage is more advanced, and for this reason the earlier begin- ning of screening has been advocated in Afro-American men (2).

The definition for the normality range of the prostate specific antigen (PSA), published in 1986 by Myrtle et al. (3), is largely accepted. This group from Hybritech, using Tanden-R assay, established the interval between 0 and $4 \mathrm{ng} / \mathrm{ml}$ as the normality range. One among 3 men with a level superior to that will show carcinoma in prostate biopsy (4). 
However, there are reports proposing changes in this range, which could vary according to race and age (1).

Gann et al. (5) showed that men with total PSA (tPSA) between 2 and $4 \mathrm{ng} / \mathrm{ml}$ are 12 -fold more likely to develop prostate cancer compared to others with tPSA below $1 \mathrm{ng} / \mathrm{ml}$, when followed during 10 years. There are studies showing that in the tPSA range between 2.5 and $4 \mathrm{ng} / \mathrm{ml}$ the prevalence of cancer reaches $24 \%$, and that is why many centers started to recommend this cut-off level for indication of biopsy (6).

In Brazil, studies on screening for prostate adenocarcinoma are scarce. The existing data present similarity in sensitivity and specificity of tPSA in a cut-off of $4 \mathrm{ng} / \mathrm{ml}$, for Southeastern population, as observed in North American population, but there are no reports of investigation using lower cut-off levels. On the other hand, 3 studies with Southeastern population involving 5,313 volunteers were not able to convincingly demonstrate a higher prevalence of prostate cancer in Afro-Brazilians than in Caucasians (7-9). It must be stressed that about $70 \%$ of Brazilian black population originate from Angola, Congo and Mozambique where the Bantu haplotype is predominant (10). The study of hemoglobin $\beta$ genes confirms that in Brazil $73 \%$ of the haplotypes are Bantu type, with Senegal haplotype being practically inexistent (11). These data reveal that AfroBrazilian are genetically distinct from North American black population, where the haplotype Benin predominates (59\%) with equivalent frequencies of Bantu and Senegal haplotypes (12). Additionally, studies based in polymorphism of nuclear and mitochondrial DNA stress the role of the intense process of miscegenation undergone by Afro-Brazilian population (urban or isolated - remainders of the quilombos) (13). The African component in black populations can range from 46 to $67 \%$ in "rural" areas, but these data do not have universal validity for urban populations (14). Obviously, the ethnic admixture is not restricted to Afro-Brazilian descendants, but it is extended to Caucasians. Such data warrant the performance of screenings in our environment aimed to racial prevalence of prostate tumor and a better characterization of PSA.

\section{MATERIALS AND METHODS}

The target population for screening consisted of 473 volunteers with ages ranging from 40 to 79 years from the city of Ipirá, Bahia. All of them underwent a digital rectal examination, blood collection for dosage of tPSA and free PSA (DPC Immulite test $) \circledR$ and DNA extraction for genetic race analysis. Volunteers with tPSA equal or superior to 2 $\mathrm{ng} / \mathrm{ml}$ or digital rectal examination suspected of prostate cancer underwent transrectal ultrasound-directed prostate biopsy (at which time the prostate volume was measured) collecting 10 fragments from the peripheral zone (15). These fragments were conserved in $10 \%$ formalin solution until their processing for histological examination following hematoxylin-eosin staining.

Volunteers were classified in White, Mulatto or Black according to anthropological criteria that considered not only the skin color aspect, but the ancestors' racial reference up to $3^{\text {rd }}$ degree (great-grandparents).

Racial genetic diversity was studied through variable number of tandem repeats (VNTR) in the DNA of 40 volunteers randomly chosen from each of the 3 racial groups defined by the anthropological criteria, as well as all bearers of neoplasia. DNA extraction was performed by a standardized technique, and its amplification (PCR) was made with 35 cycles in "Perkin-Elmer-Cetus ${ }^{\circledR}$ " thermocycler employing the following starters: APO B, vW-I Factor, D4S43, PAH and 13A1 Factor (13). The different alleles were recognized through electrophoretic migration in $4 \%$ polycrilamide gel after marking PCR products with flurochrome. Differences in molecular weight (or number of bases) were determined by comparison with migration of the "Gene Scan 2500 ROX ${ }^{\circledR}$ Kit" standard using the equipment's "ABIPrism 377@" software. The organization of the database with frequency of alleles for comparison between groups was done by the GDA software (16). That computerized VNTR database was employed as a reference, with data on descendants with European origin (Portuguese, Spanish, Italian and German - urban region of Ribeirão Preto), Africans from Congo and Cameroons (origin: Lubumbashi and Yaoundé) and Amerindian 
from isolated tribes of Pará (Arara, Wayana-Apalai, Wayampi, Yanoman and Kayapo) (13). The estimate of ethnic admixture was calculated by the ADMIX 3 software (17).

The variables related to cancer prevalence, PSA test and other characteristics of the sample were performed by the Graph Prism ${ }^{\circledR}$ software version 3.0. Classificatory attributes were analyzed by Fisher's exact test or $\chi^{2}$. Continuous variables of normal distribution were compared by unpaired bi-caudal " $\mathrm{t}$ " test or variance analysis, and those which did not pass the normality test were assessed by non parametric test. The significance level was fixed in $5 \%$.

\section{RESULTS}

Of the 473 volunteers, 148 (31.3\%) were White, 90 (19\%) Mulatto and 235 (49.7\%) Black according to the anthropological criteria. Respective mean age in these groups was: $56.8 \pm 9.5$ years, $54.7 \pm 10.7$ years and $57.9 \pm 9.5$ years. Simultaneous comparison between the groups by variance analysis showed $p=$ 0.03 . Tukey test showed similarity between White and Black, as well as between White and Mulatto groups, but not between Mulatto and Black groups. The comparison of mean age of Whites and non-Whites by the t-test showed no difference $(\mathrm{p}=0.8)$.

Biopsies were indicated and performed in 121 volunteers. The prevalence of prostate adenocarcinoma for a tPSA cut-off level of 2 or $2.5 \mathrm{ng} / \mathrm{ml}$ was $5.7 \%$, or $27 / 473$ men, with ages ranging from 40 to 79 years, and $7.9 \%$ or $27 / 341$ volunteers with ages between 50 and 79 years. If a tPSA cut-off level of 4 $\mathrm{ng} / \mathrm{ml}$ was considered the prevalence would be $23 /$ $473(4.8 \%)$ between 40 and 79 years, and 23/341 (6.7\%) from 50 to 79 years.

Tumor occurred in 1 White, 6 Mulattos and 20 Blacks. Simultaneous comparison of cancer prevalence in the 3 groups, according to the anthropological criteria, showed a high significance $(\mathrm{p}=0.005)$. The comparison between groups showed the following results: White versus Black: $p=0.008$, White versus Mulatto: $p=0.01$, White versus non-White: $\mathrm{p}=0.009$ and Mulatto versus Black: $\mathrm{p}=0.65$.

The mean values of admixture rate of African, Caucasian and Amerindian genes, in the samples classified by anthropological criteria as White, Mulatto or Black are exposed in Table-1. The gene admixture in volunteers with or without cancer regardless of anthropological phenotype is presented in this Table as well.

Tumor ratios in tPSA ranges from 2.1 to 4 $\mathrm{ng} / \mathrm{ml}$, from 2.5 to $4 \mathrm{ng} / \mathrm{ml}$, from 4 to $10 \mathrm{ng} / \mathrm{ml}$ and $>10 \mathrm{ng} / \mathrm{ml}$ were respectively: $6 / 62(9.6 \%), 6 / 43$ (13.9\%), 7/35 (20\%) and 14/30 (77.7\%). The performance of the tPSA test in 3 cut-off levels in volunteers with tPSA $\leq 10 \mathrm{ng} / \mathrm{ml}$ is exposed in Table-2.

Table- 3 shows the performance of digital rectal examination as well as a simulation of influence, on the performance of tPSA, of free/total PSA ratio and of PSA density in cases they were used. For simulation, the selection of cut-off levels of free/total PSA ratio and PSA density was made in such a way to maintain the sensitivity of total PSA according to the cut-off level.

Table 1 - Analysis of gene admixture in "Whites", "Mulattos” and "Blacks" from Ipirá, Bahia, Brazil, as classified under an anthropological perspective.

\begin{tabular}{lccccc}
\hline \multirow{2}{*}{ Alleles } & \multirow{5}{c}{ Residents in Ipirá } \\
& Whites & Mulattos \% & Blacks \% & With Cancer \% & Without Cancer \% \\
\hline Caucasians & $67.5 \pm 8$ & $54.8 \pm 9$ & $45.3 \pm 3$ & $50.5 \pm 9$ & $59.1 \pm 7$ \\
Africans & $20.8 \pm 8$ & $36.3 \pm 5$ & $45.9 \pm 4$ & $49.0 \pm 8$ & $31.7 \pm 8$ \\
Amerindians & $11.7 \pm 7$ & $8.9 \pm 7$ & $8.8 \pm 4$ & $0.5 \pm 4$ & $9.2 \pm 5$ \\
Total & 100.0 & 100.0 & 100.0 & 100.0 & 100.0 \\
\hline
\end{tabular}


Table 2 - Performance of total PSA test in different cut-off levels for all volunteers with PSA $<10.1 \mathrm{ng} / \mathrm{ml}$.

\begin{tabular}{lccccc}
\hline Cut-off Level & Ss \% & Sp \% & PPV \% & NPV \% & Accuracy \\
\hline $2.0 \mathrm{ng} / \mathrm{ml}$ & 100 & 6.6 & 13.4 & 100 & 18.4 \\
$2.5 \mathrm{ng} / \mathrm{ml}$ & 100 & 36.6 & 18.0 & 100 & 42.7 \\
$4.0 \mathrm{ng} / \mathrm{ml}$ & 69.2 & 62.2 & 20.9 & 93.3 & 63.1 \\
\hline
\end{tabular}

Ss - sensitivity; Sp-specificity; PPV-positive predictive value; NPV-negative predictive value.

\section{DISCUSSION}

The prevalence of prostate cancer in volunteers from Bahia community (Northeastern) under study seems equivalent to those found in the State of São Paulo since those ranged from $1.3 \%$ to $3.2 \%(7-9,18)$. It must be stressed that in Northeastern volunteers the prevalence would be $4.8 \%$ if a tPSA cut-off level $4 \mathrm{ng} / \mathrm{ml}$ was employed, and that the performance of biopsies with collection of 10 peripheral fragments can lead to a $35 \%$ addition in cancer diagnosis compared to the sextant biopsy (15). In developed countries, the prevalence of prostate cancer in screenings has ranged from $1 \%$ to $6 \%$ in the age range from 50 to 75 years $(1,4,6)$, which appears to indicate a similarity with our population.

Tumor prevalence in Blacks and Mulattos, alone or jointly, was statistically superior to that found in Whites from Ipirá. However the prevalence in Blacks and Mulattos was similar.
The difference in racial prevalence observed in this work cannot be explained based on age composition of groups, but it could be casual (despite significant), mainly due to the low prevalence observed in the White sample (1/148 - 0.7\%).

When confronting the anthropological classification with the genetic composition, a marked process of ethnic admixture is observed in that region. What strongly suggests that Bantu ancestry is associated to a higher prevalence of prostate cancer is that in tumor bearers the proportion of African alleles was $49 \%$ whereas in those without cancer it was $31.7 \%$ (Table-1). However, it is remarkable that the proportion of Amerindian alleles in volunteers without cancer was approximately 18 times higher $(9.2 \%)$ than the one observed in neoplasia bearers $(0.5 \%)$. Could it be that the Amerindian (Asiatic) genes were counterbalancing the role of African genes in a higher predisposition to cancer?

Table 3 - Some performance parameters of methods for indication of prostate biopsies, alone or associated, for the volunteers set with total PSA from 0 to $10 \mathrm{ng} / \mathrm{ml}$.

\begin{tabular}{|c|c|c|c|c|c|c|}
\hline \multirow[t]{2}{*}{ Method } & \multirow[t]{2}{*}{ Ss \% } & \multirow[t]{2}{*}{ Sp \% } & \multicolumn{2}{|c|}{ Biopsies } & \multirow{2}{*}{$\begin{array}{c}\text { Missed } \\
\text { Tumors }\end{array}$} & \multirow{2}{*}{$\begin{array}{c}\mathbf{N}^{\circ} \text { of Biopsies } \\
\text { per Diagnosed Tumor }\end{array}$} \\
\hline & & & Done & Avoided & & \\
\hline Digital rectal examination & 15.3 & 83.3 & 17 & 86 & $11 / 13$ & 8.5 \\
\hline tPSA $2 \mathrm{ng} / \mathrm{ml}$ & 100 & 6.6 & 97 & 6 & $0 / 13$ & 7.4 \\
\hline tPSA $2.5 \mathrm{ng} / \mathrm{ml}$ & 100 & 36.6 & 72 & 31 & $0 / 13$ & 5.5 \\
\hline $\mathrm{tPSA} 4 \mathrm{ng} / \mathrm{ml}$ & 69.2 & 62.2 & 43 & 60 & $4 / 13$ & 4.7 \\
\hline $\mathrm{tPSA} 2.5 \mathrm{ng} / \mathrm{ml}+\mathrm{F} / \mathrm{T}$ PSA $20 \%$ & 100 & 52.2 & 56 & 47 & $0 / 13$ & 4.3 \\
\hline tPSA 4 ng/ml + F/T PSA $20 \%$ & 69.2 & 80.0 & 27 & 76 & $4 / 13$ & 3.0 \\
\hline tPSA $2.5 \mathrm{ng} / \mathrm{ml}+$ PSAD 0.08 & 100 & 51.1 & 57 & 46 & $0 / 13$ & 4.3 \\
\hline $\mathrm{tPSA} 4 \mathrm{ng} / \mathrm{ml}+\mathrm{PSAD} 0.10$ & 69.9 & 70.0 & 36 & 67 & $4 / 13$ & 4.0 \\
\hline
\end{tabular}

tPSA - total PSA; F/T PSA - free/total PSA; PSAD - PSA density; Ss - sensitivity; Sp - Specificity. 
The explanation for the difficulty in demonstrating a higher prevalence of tumor in Southeastern Blacks is not simple with data published up to now. One study about miscegenation in a Southeastern region using the same criteria for anthropological (considering also the ancestry) and genetic (VNTR) classification, as it can be seen on Table-4 (13), seems to show some ethnic differences between Southeastern and Northeastern samples. The sample studied in the Northeast suggests a markedly lower crossing proportion between Caucasian and Indians since the percentage of Amerindian alleles in Whites was approximately 2.5 times lower (4.6\%) than in the Northeastern sample (11.7\%). That means that the proportion of Amerindian alleles in the Northeastern Whites sample is $154 \%$ higher than the Southeastern one, which would allow us to speculate if this would be the factor responsible for the low prevalence of tumor in Whites of that city. Other differences are less significant, even though it can be stressed that in the Southeast the proportion of African alleles in Whites was $14.9 \%$ higher, of Amerindian alleles in Blacks was $23.8 \%$ higher and of African alleles in Blacks was $14.3 \%$ higher than those found in the Northeastern. Thus, it is possible that the difference in prevalence among regions can be explained by ethnic diversity. Another explanation could be the lower longevity of Blacks pointed out in one of the Southeastern studies (7). However, maybe the main reason is the difference in criteria for anthropological classification, or even the difficulty or limitations for its application in a mixed population, because it is not clear if in other screenings the racial antecedent was considered.

Table 4 - Ethnic admixture in residents from the urban region of Ribeirão Preto classified in Whites, Mulattos and Blacks according to anthropological criteria (13).

\begin{tabular}{lccc}
\hline & \multicolumn{3}{c}{ Residents in Ribeirão Preto } \\
Alleles & Whites \% & Mulattos \% & Blacks \% \\
\hline Caucasians & $71.4 \pm 5$ & $49.5 \pm 8$ & $36.4 \pm 3$ \\
Africans & $23.9 \pm 6$ & $40.1 \pm 4$ & $52.5 \pm 4$ \\
Amerindians & $4.6 \pm 4$ & $10.3 \pm 6$ & $10.9 \pm 4$ \\
Total & 100.0 & 100.0 & 100.0 \\
\hline
\end{tabular}

Our study also suggests that the sensitivity of tPSA, cut-off of $4 \mathrm{ng} / \mathrm{ml}$, in the group of volunteers with tPSA below or equal to $10 \mathrm{ng} / \mathrm{ml}$, is unsatisfactory. Of the 13 tumors found in this range, 6 were associated to tPSA $<4 \mathrm{ng} / \mathrm{ml}$, and $4(30.7 \%)$ of them would not have been diagnosed because the digital rectal examination did not suggest a tumor. On the other hand, the cut-off of $2 \mathrm{ng} / \mathrm{ml}$ presented a very low specificity, which meant a large proportion of unnecessary biopsies. The combination of tPSA cutoff in $2.5 \mathrm{ng} / \mathrm{ml}$ associated to additional criteria for indication of biopsy, such as free/total PSA ratio in $20 \%$ or PSAD in 0.08 , seemed to represent a better option than employing only tPSA in all other cut-off levels. In the literature, results are controversial and there is no agreement about the best cut-off level for tPSA, as well as about the benefits gained with the associated use of the free/total PSA ratio and tPSA density, but one can note a tendency towards recommending a reduction in the cut-off level of tPSA and applying associated parameters in order to improve the test specificity $(4,6)$. Maybe the most convincing recent multiracial study about the subject involving the screening and the follow-up of 12,902 men, of whom 7,541 were considered without prostate disease, showed that $95 \%$ of the sample without disease had tPSA $\leq 2.45 \mathrm{ng} / \mathrm{ml}$, and this is the reason why this value was proposed as the upper limit for normality (19). Nevertheless, it must be stressed that the cut-off level of the free/total PSA coefficient that is able to maintain the tPSA sensitivity above $90 \%$, in the same sample of patients, varies considerably with the brand of reagent that is used (20).

\section{CONCLUSION}

The prevalence of prostate cancer in Ipirá, Bahia, Brazil, was $5.7 \%$, being higher in Blacks and Mulattos than in Whites. In cancer bearers the mean proportion of African alleles was $49 \%$, whereas in those without cancer it was $31.7 \%$. In volunteers with tPSA $\leq 10 \mathrm{ng} / \mathrm{ml}$, the use of a cut-off level for tPSA in $2.5 \mathrm{ng} / \mathrm{ml}$, the free/total PSA fraction of $20 \%$ and tPSA density of 0.08 , represented a better option for indication of biopsies than the isolated use of tPSA in a cut-off level of $4 \mathrm{ng} / \mathrm{ml}$. 


\begin{abstract}
The project was supported by the Research Support Foundation of the State of São Paulo

(FAPESP) and by the Teaching, Research

and Assistance Support Foundation of the

General Hospital of Ribeirão Preto - USP(FAEPA).
\end{abstract}

\section{REFERENCES}

1. Oesterling JE, Jacobsen SJ, Chute CG, Guess HA, Girman CJ, Panser LA, et al.: Serum PSA in a community-based population of healthy men: establishment of age-specific reference range. JAMA 1993; 270: 860-4.

2. Kronkad A, Lai H, Lamm SH, Lai S: Mortality in prostate cancer. J Urol. 1996; 156: 1084-91.

3. Myrtle JF, Klimley PG, Ivor IP, Bruni JF: Clinical utility of prostate specific antigen (PSA) in the management of prostate cancer. Hybritec Inc., San Diego, CA, 1986: 1-4.

4. Siegal J, Brawer MK: Prostate Specific Antigen. In: Kaisary AV, Murphy GP, Denis L, Griffiths K (ed.), Text Book of Prostate Cancer, Pathology, Diagnosis and Treatment. London, Martin Dunitz. 1999; pp. 121-41.

5. Gann PJ, Hennekens CH, Stampfer MJ: A prospective evaluation of plasma prostate specific antigen for detection of prostatic cancer. JAMA 1995; 273: 289-94.

6. Arcangeli CG, Ornstein DK, Keeth DW, Andriole GL: Prostate-specific antigen as a screening test for prostate cancer. The United States experience. Urol Clin North Am. 1997; 24: 299-306.

7. Martins AC, Reis RB, Suaid HJ, Maciel LM, Cologna AJ, Falconi RA: Screening for carcinoma of the prostate in volunteers. Int Braz J Urol. 2000; 26: 516-22.

8. Antonopoulos IM, Pompeo AC, El Hayek OR, Sarkis AS, Alfer Jr W, Arap S: Results of prostate cancer screening in non-symptomatic men. Int Braz J Urol. 2001; 27: 227-34.

9. Glina S, Toscano Jr IL, Mello LF, Martins FG, Vieira VL, Damas CG: Results of screening for prostate cancer in a community hospital. Int Braz J Urol. 2001; 27: $235-43$.

10. Curtin, PD: The atlantic slave trade: a census. Madson/ London, University of Wisconsin Press, 1969.

11. Zago MA, Figueiredo MS, Ogo SH: Bantu $\beta^{\text {s }}$ cluster haplotype predominates among Brazilian blacks. Am J Phys Anthropol. 1992; 88: 295-8.

12. Antonarakis SE, Boehm CD, Serjeant GR, Theisen CE, Dover GJ, Kazazian Jr HH: Origin of the $\beta^{s}$ - globin gene in blacks: The contribution of recurrent mutation or gene conversion or both. Proc Natl Acad Sci USA. 1984; 81: 3853-6.

13. Silva Jr, WA: Genetic Diversity in Afro-Brazilian Populations. Thesis. Ribeirão Preto School of Medicine - USP, 1999 [in Portuguese].

14. Bortolini MC, da Silva-Junior WA, Weimer TA, Zago MA, de Guerra DC, Schneider MP, et al.: Protein and hypervariable tandem repeat diversity in eight Africanderived South American populations: inferred relationships do not coincide. Hum Biol. 1998; 70: 443-61.

15. Eskew LA, Bare LR, McCullough DL: Systematic 5 region prostate biopsy is superior to sextant method for diagnosing carcinoma of the prostate. J Urol. 1997; 157: 199-203.

16. Lewis PO, Zaykin D: Genetic Data Analysis: computer program for the analysis of allelic data. Version 1.0, Internet, GDA Home Page <http://chee.unm.edu/gda/>, 1997.

17. Chakraborty R: Gene admixture in human populations: Models and predictions. Am J Phys Anthropol. 1986; 29: 1-5.

18. Fonseca FP, Veneziano DB, Betti RC, Okawa CO: Serum levels of prostate specific antigen in patients screened for prostate cancer. Int Braz J Urol. 2001; 27: $32-6$.

19. Cheli CD, Levine R, Cambetas DR, Kolker JD, Roberts SB: Age-related reference ranges for complexed prostate-specific antigen and complexed/total prostatespecific antigen ratio: results from East Texas Medical Center Cancer Institute screening campaign. Urology 2002; 60 (Suppl A): 53-9.

20. Taille A, Houlgatte A, Houldellete P, Goluboff ET, Berlizot P, Ricordel I: Influence of free-to-total prostate specific antigen variability on the early diagnosis of prostate cancer: a comparative study of three immunoassays. Br J Urol. 1998; 82: 389-92.

$$
\begin{array}{r}
\overline{\text { Received: April 4, } 2003} \\
\text { Accepted after revision: May 20, } 2003
\end{array}
$$

\footnotetext{
$\overline{\text { Correspondence address: }}$

Dr. Antonio C. P. Martins

Hospital das Clínicas da FMRP - USP

Av. Bandeirantes, $3900 / 9^{\circ}$ andar

Ribeirão Preto, SP, 14049-900, Brazil

Fax: + 5516 633-0836

E-mail: acpmartins@convex.com.br
} 